\title{
Responding to Hammond's Call to Action for Universities
}

\author{
Lynette Shultz, University of Alberta \\ 1shultz@ualberta.ca
}

Interest in the Israel- Palestine conflict comes from many locations and carries many perspectives. The recent special issue of the Journal of Cultural and Pedagogical Inquiry (2010, Vol 2, No. 2) gathered four articles that examined how educators responded to the conflict within educational environments in Canada. In this issue, Keith Hammond's article continues this discussion with a call to universities, in all parts of the world, to join in political action that might force some resolution to the ongoing injustices that have become a daily reality for Palestinians located in the conflict areas and beyond. In this short article, rather than repeat the details of the case so fully described by Hammond, I would like to respond to Hammond's call by highlighting the questions that his historical and political descriptions surface for universities.

In the 1980's, led by the work of Mary Douglas, academics pondered if "institutions can think" (1986). Was there a way to understand the policies and decisions made in institutions as collective bodies representing the interests and activities of the people with whom they were associated? Hammond demands that we ask: Can institutions act? And if so, can they act for justice and in solidarity within a contested public sphere? He clearly, and with great passion, articulates the social justice foundation of such questions by describing the human tragedy caused by the ongoing de-development of Palestinians by the state of Israel. If universities, acting in solidarity with de-citizenized Palestinians and with other institutions of higher education, can have a significant role in creating a just resolution to this conflict with renewed life chances and human dignity for Palestinians, then why should there be any question about whether or not there should be direct and immediate action? Universities have long declared their vision of contributing to a strong society and human wellbeing through educating not only knowledgeable professionals but also critical and engaged citizens. But how do these visions become actualized? Are they through "negative" approaches where space is created or held open for transformative education through ensuring academic freedom and resisting the implementation of policies or programs that would impede transformational and critical pedagogical projects within the university? Or is it through "positive" approaches where policies are established that promote and require particular activities and programs become part of the university? Hammond calls for the latter in the form of boycotts and divestments that are linked to a wider social movement in solidarity with other social institutions around the world, much like global movements that contributed to ending apartheid in South Africa.

Castells (2001) highlighted that universities play multiple roles in society including acting as ideological apparatuses and contributing to related struggles; the socialization of elites; the generation of knowledge; and preparing a skilled workforce. Brennan, King \& Lebeau (2004) in 
a multi-country study found that universities more often played contradictory roles in more transformational social, political or economic projects and with many other educators (for example, Paulo Freire, 1970) suggests, education is always moving between social reproduction and social transformation. In fact, Freire's work highlights that these are the only choices there are; to attempt acts of neutrality is in fact, siding with the dominant forces and the status quo. As educators, we can either reproduce things as they are or we can be part of changing them. Universities as the collective organization of these education decisions should certainly be considered actors, with ongoing contributions made (or in some cases, withheld) to society and the public sphere.

So how should we respond to Hammond's call for justice and his demand for action? If universities, through action or inaction, are serving to perpetuate/ reproduce a de-humanizing social reality these same institutions can mobilize their capacity as social transformers toward the goal of political and social change. If the stakes are as high as we see in the Israel-Palestine conflict, where daily violence continues to take its toll, it would seem imperative that a range of immediate to long-term responses be instituted. These will be reflections of the range of institutional contributions of higher education in society: contributions to knowledge about current ideologies and struggles in the form of courses, lectures, and community engagement; to preparing critical citizens able to understand the conflict and take action through creating critical pedagogical spaces including student groups and formal classes; and contributions to authentic social and economic development of people who are being denied their human dignity through the actions and inactions of all societies' institutions. As Hammond has outlined, engaging in boycotts and divestments until the conflict is resolved and justice is restored can be an important institutional action that contributes to a wider social movement and demonstrates that, indeed, institutions can act.

\section{References}

Brennan, J., King, R., Lebeau, Y. (2004). The role of universities in the transformation of societies. An international research project. Synthesis Report. London: ACU/Open University.

Castells, M. (2001). Universities as dynamic systems of contradictory functions. In Muller, Cloete \& Badat (Eds). Challenges of Globalisation: South African Debates with Manuel Castells. Cape Town: Maskiw Miller Longman. pp 206-223. Accessed 07/12/11 at http://books.google.ca/books.

Douglas, M. (1987). How institutions think. London: Routledge.

Freire, P. (1970). Pedagogy of the oppressed. New York: Continuum Publishers. 